\title{
How Law Student Prepare Their Life to Survive?
}

Character Education Training for Student Activists in order to Prepare Superior Indonesian Human Resources with the Character of Pancasila

\section{Aprila Niravita $^{1 *}$, Benny Sumardiana ${ }^{2}$, Bayangsari Wedhatami ${ }^{3}$, Syukron Salam ${ }^{4}$, Ubaidillah Kamal ${ }^{5}$, Batari Laskarwati ${ }^{6}$, Iqbal Syariefudin 7 \\ 1,2,3,4,5,7 Faculty of Law, Universitas Negeri Semarang, Indonesia \\ ${ }^{6}$ Postgraduate Program, Master of Laws, Universitas Negeri \\ Semarang, Indonesia}

Corresponding Author: A. Niravita, email: aprilaniravita@mail.unnes.ac.id

\begin{abstract}
Character education is an important element in the effort to prepare superior Indonesian human resources, it is of particular concern to be applied especially among students, there is a need for character education because the attitudes and behavior of the people and people of Indonesia now tend to ignore the noble values of Pancasila which are highly respected and should be rooted in everyday attitudes and behaviors, values such as honesty, politeness, togetherness and religious, gradually eroded by foreign cultures that tend to be hedonistic, materialistic, and individualistic, so that the noble character values are ignored in the future if students and young people are not equipped with character education. Law students have their own challenges, especially in the era of globalization. This paper analyzes and illustrates the character strengthening program for law student activists in Semarang State University through several programs, namely public speaking, strengthening student idealism, strengthening advocacy capacitation and human rights assistance and self-motivation. This research is a field research with the object of research as activists of law students who are members of student organizations. This research confirms that the programs for strengthening the character of students experience several obstacles, one of which is the model used and a relatively short time. However, character education for student activists helps students to survive in real life as part of community members.
\end{abstract}

Keywords: Law Student, Character Education, Pancasila Character

\section{How to cite:}

Niravita, A., Sumardiana, B., Wedhatami, B., Salam, S., \& Syariefudin, I. (2020). How Law Student Prepare Their Life to Survive?. Indonesian Journal of Advocacy and Legal Services, 2(1), 19-38. https://doi.org/10.15294/ijals.v2i1.36764 


\section{A. Introduction}

Kompas Newspaper reported that based on the corruption perception index, carried out by the Transparency International survey agency, Indonesia was still among the most corrupt countries ranked 118 th out of 174 countries. ${ }^{1}$ In the same daily, the DPR Honorary Board reported that there were 28 board members involved in ethical issues. The country is in a multidimensional crisis that never ends, conditions are exacerbated by a moral crisis and the character of the nation's leaders who impact on the younger generation. Student brawls, free sex, drug abuse, shameless culture, values and norms are declining not only in urban areas but have spread to the countryside ${ }^{2}$. As a preventive alternative, education is expected to develop the quality of the nation's young generation in various aspects that can minimize and reduce the causes of various cultural problems and national character. Efforts to overcome these conditions will require understanding and steps to rebuild the nation's character in accordance with the values of Pancasila.

The curriculum is not a standard and static standard, but it is very dynamic and adapts to the existing situations and conditions ${ }^{3}$. In the last few years our education has undergone several curriculum changes. Our curriculum has so far been considered too complex which is a burden on students because it is too focused on intellectual intelligence. This results in many students who are unable to keep up with the burden of learning feeling uneasy at school and diverting their activities with deviant things. To respond to the above phenomenon, education reform is very important, namely by creating an educational curriculum that has cultural values and national character.

According to Sartono, the character referred to in education is the character of the Indonesian people in accordance with the values of Pancasila, among others, Faith and Devotion, Honest and Clean, Courteous and Smart, Responsible and Hard Work, Discipline and Creative, Caring and Helping. Therefore, with character education it is hoped that character education is integrated in every subject so that with the existence of character education it is hoped that Indonesia's future will be better. ${ }^{4}$

Kompas. (2012, Desember). Retrieved from www. http://internasional.kompas.com.

2 Zuriah, N, Pendidikan Moral dan Budi Pekerti Dalam perspektif Perubahan. Jakarta, Bumi Aksara, 2007, pp. 57-58.

3 Marzuki, "Pengintegrasian Pendidikan Karakter dalam Pembelajaran di Sekolah" Jurnal pendidikan Karakter, 2(1), 2012, pp. 33-44. DOI: https://doi.org/10.21831/jpk.v0i1.1450

4 HM Sartono, Pengintegrasian Pendidikan Karakter dalam Pengembangan Kurikulum Tingkat Satuan Pendidikan, 2011, (Online), from http://www.slideshare.net/sarhaji/pengintegrasianpendidikan-karakter-dalampengembangan-kurikulum10099847 
Character education is an important element in the effort to prepare superior Indonesian human resources, it is of particular concern to be applied especially among students, there is a need for character education because the attitudes and behavior of the people and people of Indonesia now tend to ignore the noble values of Pancasila which are highly respected and should be rooted in everyday attitudes and behaviors, values such as honesty, politeness, togetherness and religious, gradually eroded by foreign cultures that tend to be hedonistic, materialistic, and individualistic, so that the noble character values are ignored in the future if students and young people are not equipped with character education.

According to Thomas Lickona ${ }^{5}$, terminologically the character is " $A$ reliable inner dispotion to respond to situations in a morally good way." Lickona also emphasized that, "Character so conveived has three interrelated parts, moral knowing, moral feeling, and moral behavior". This means that good character must include the knowledge of goodness, then grow commitment (intention) to goodness and ultimately do good itself. In other words, good character education must involve good knowledge (moral knowing), good feeling or loving good (moral feeling) and good behavior (moral action) so that the embodiment of behavior and life attitude of students is formed.

Some previous researches stated that there are 4 basic pillars of the moral values of character education, namely: intellectual development, spiritual and emotional development, physical and kinesthetic development, physical and kinesthetic development), and if the taste and intention (affective and creativity development). ${ }^{6}$

Character itself recognized as the integrity of all psychological behavior resulting from the influence of endogenous (genetic) and exogenous (environmental) factors, which are imprinted on oneself that distinguish

\footnotetext{
As quoated by Marzuki, Op.Cit.

HM Sartono, Op.Cit; Semiawan, C.R., "Peran Pendidikan dalam Pembangunan Karakter Bangsa”, Makalah Konferensi Nasional \& Workshop Assosiasi Psikologi Pendidikan Indonesia, Oktober, 2010; Rose Mini, A.P., "Perkembangan Moral sebagai Dasar Pendidikan Karakter Anak, Makalah Konferensi Nasional \& Workshop Assosiasi Psikologi Pendidikan Indonesia, Oktober, 2010; Ajisuksmo, C., "Pendidikan Karakter, Makalah Konferensi Nasional \& Workshop Assosiasi Psikologi Pendidikan Indonesia, Oktober, 2010; Eviatun Khaeriah, "Konsep Pengembangan Pendidikan Karakter Sebagai Pembentuk Identitas Diri Remaja dalam Perspektif Teori Identitas Erikson (Studi Kritis di SMK Negeri 2 Malang)", Master Thesis, 2011, Universitas Muhammadiyah Malang; Dian Ratna Sawitri \& Jati Arianti, "Malas, Ngantuk, Bosan: Hambatan Mahasiswa untuk Mencapai Indeks Prestasi Tinggi", Proceedings Konferensi Nasional dan Workshop Asosiasi Psikologi Pendidikan Indonesia, 2010, pp. 211-215.
} 
individuals or groups of individuals from one another. ${ }^{7}$ Licona $^{8}$ illustrates that character is a form of morally appropriate behavior consisting of good qualities or in other words character is a form of concrete behavior or application of morals. While character education is a system of inculcating religious values, law, etiquette, culture and customs to school members including components of knowledge, awareness or willingness, and actions to carry out these values both to God, self, others, the environment and to the nation to become our human being. ${ }^{9}$ Furthermore, in the same context, Megawangi states that character education must be carried out holistically, meaning that it must be done together by teachers, parents and the environment and must touch all aspects of a child's life that aims to develop throughout human dimension. ${ }^{10}$

Character education, especially in College Student become one of the most important things in education sector. ${ }^{11}$ Various problems in the higher education still continue to occur, for instance violent behavior and brawl, the emergence of the seeds of radicalism and the lack of nationalism, political contamination in the world of education, immoral acts and promiscuity, misuse of illegal drugs, and various other cases. ${ }^{12}$ In fact, students are considered as part of the Indonesian nation which is a civil society and

7 Semiawan, C.R, "Peran Pendidikan dalam Pembangunan Karakter Bangsa. Makalah Konfrensi Nasional \& Workshop Assosiasi Psikologi Pendidikan Indonesia, October, 2010.

8 As quoted by Rose Mini, A.P., "Perkembangan Moral Sebagai Dasar Pendidikan Karakter Anak". Makalah Konfrensi Nasional \& Workshop Assosiasi Psikologi Pendidikan Indonesia, October, 2010.

9 Ajisuksmo, C. Op.Cit

10 Megawangi, R., "Strategi dan Implementasi Model Pendidikan Holistik Berbasis Karakter", Makalah Konfrensi Nasional \& Workshop Assosiasi Psikologi Pendidikan Indonesia, October, 2010

11 College Students are recognized as agent of change, in fact, students also recognized as "iron stock", we as students are expected to be human beings who have the ability and noble character, here we play a role as a substitute for previous generations. Namely, we as the forerunner or reserve for a period that will advance our nation. Because if we are not young people who will be the nation's successors, then who else will advance our beloved nation in Indonesia, See Aprila Niravita, "The Role of Law Students on Strengthening Village Human Resources in the Era of the Industrial Revolution 4.0", Indonesian Journal of Advocacy and Legal Services, 1(1), 2019, pp. 1-4. https://doi.org/10.15294/ijals.v1i1.33802; Ridwan Arifin, Riska Alkadri, Dewi Puspa Sari, Lilies Resthiningsih, \& Amarru Muftie Holish, "Improving Law Student Ability on Legal Writing through Critical and Logical Thinking by IRAC Method", Indonesian Journal of Advocacy and Legal Services, 1(1), 2019, pp. 107-128. https://doi.org/10.15294/ijals.v1i1.33706

12 Ferly Ferdyant, Tantangan-Tantangan Dalam Pendidikan Karakter: Catatan Awal Tahun 2018 IKA UNJ, 2018, https://unjkita.com/tantangan-tantangan-dalampendidikan-karakter-catatan-awal-tahun-2018-ika-unj/; Rakhmat Hidayat, Robohnya Moralitas Kampus, 17 November 2014, https://republika.co.id/berita/nf6agc45/robohnyamoralitas-kampus 
concerned with the nation's education, it should be students to instill and make the values of the noble character contained in the Pancasila that we grow and blossom again in accompanying each of our attitudes and behaviors, that is in order to create superior human resources who are able to compete in the midst of other nations. One effort to achieve this is through character building in all aspects of community life, especially through educational institutions. Building the nation's character does take a long time and is carried out continuously. Character education training is one of the efforts to make improvements and build such character so that Indonesian people, especially students achieve the direction and objectives of national education, as mandated by the 1945 Constitution, which aims to increase faith and piety and fostering the noble morals of the students which in this case are all Indonesian citizens who take part in the education process in Indonesia.

\section{B. Method}

This research is a field research, where this research directly involves respondents through training programs and character education for students. This study aims to find out the character education training for students in strengthening the attitude of nationalism and patriotism. This research involved students of the Faculty of Law, Semarang State University, Indonesia. The limitation of character on this research based on the translation of character itself. Ryan \& Bohlin emphasized the definition of character that the word character comes from the Greek charassein, which means to engrave (painting, drawing), like people who paint paper, sculpt stone or metal. Rooted from such an understanding, the character is then interpreted as a sign or a special feature, and therefore gives birth to the view that the character is a pattern of behavior that is individual, one's moral state? After passing through the stage of children, someone has a character, a predictable way that a person's character is related to the behavior that is around him. ${ }^{13}$

Good character is related to knowing the good, loving the good, and acting the good. These three ideals are closely related to one anothers. Someone is born in a state of ignorance, primitive impulses that exist in him may be able to command or master his reason. Thus, the effects that accompany a person's pattern of nurturing and education will be able to direct

13 Kevin Ryan \& Karen E. Bohlin, Building Character in Schools: Practical Ways to Bring Moral Instruction to Life. San Francisco: JOSSEY-BASS A Wiley Imprint, 1999, pp.1516, See also Ajat Sudrajat, "Mengapa Pendidikan Karakter?", Jurnal Pendidikan Karakter, 1(1), October, 2011, pp. 47-58. 
the tendencies, feelings, and great passions to be in harmony with the guidance of reason and teachings religion. ${ }^{14}$

This research was conducted at the Faculty of Law, Universitas Negeri Semarang (UNNES). Research uses a qualitative descriptive ${ }^{15}$ approach with a single embedded case study strategy. Data sources came from informants namely faculty leaders, lecturers and students within the scope of the Faculty of Law UNNES; behavior or activities of informants (law student activists); UNNES Faculty of Law environment; as well as documents and drawings related to the implementation of character education in achieving the vision of the Faculty of Law UNNES. Informants were taken with a purposive sampling technique, which is choosing informants who are considered to know information and problems that will be studied in-depth and can be trusted to be a reliable source of data. Data collection techniques carried out by in-depth interviews, observation, and document analysis. Data validity uses source triangulation. Data analysis uses interactive data analysis techniques, namely the stages: data collection, data reduction, data presentation, drawing conclusions, and verification.

\section{Result and Discussion}

\section{How Law Students Prepare Their Life? Understanding the Character Edution for Law Students (Case of Universitas Negeri Semarang)}

Education is a conscious and planned effort to create a learning atmosphere and learning process so that students can actively develop their

14 Ajat Sudrajat, Ibid.

15 Qualitative research is research that is descriptive and tends to use analysis. The process and meaning (subject perspective) is more highlighted in qualitative research. The theoretical foundation is used as a guide so that the focus of research is in accordance with the facts in the field. Besides this theoretical foundation is also useful to provide a general description of the research background and as a material discussion of research results. There is a fundamental difference between the role of the theoretical foundation in quantitative research with qualitative research. In quantitative research, research departs from theory to data, and ends in acceptance or rejection of the theory used; whereas in qualitative research the researcher departs from the data, utilizes existing theories as explanatory material, and ends with a "theory", See Ridwan Arifin, Waspiah, Dian Latifiani, Penulisan Karya Ilmiah untuk Mahasiswa Hukum, Semarang, BPFH UNNES, 2019, pp. 76-79; Ridwan Arifin, "Crimes and Society, How Do the Law Respond to Disruptive Conditions?", Law Research Review Quarterly, 6(1), 2020, pp. i-iv. Retrieved from https://journal.unnes.ac.id/sju/index.php/snh/article/view/37437; Ridwan Arifin, "Legal Reform Discourse in Indonesia and Global Context: How Does the Law Respond to Crime", Journal of Law and Legal Reform,1(2), 2020, pp. 193-196. https://doi.org/10.15294/jllr.v1i2.37057 
potential to have spiritual spiritual strength, self-control, personality, intelligence, noble character, and the skills needed by themselves, society, nation and state. Education is an effort that is arranged and planned to influence other people, whether individuals, groups or communities so that they do what is expected by the actors of education where education can change and organize society and the nation.

Character education is a process of education that is oriented to the process of fostering the potential that exists in students, developed through the habituation of good traits in the form of teaching and instilling good character values to be implemented in daily life, character education is education that is not oriented on cognitive aspects only.

Academically, character education is interpreted as education values, character education, moral education, character education, or moral education whose aim is to develop students' abilities to make good and bad decisions, maintain what is good, and realize that goodness in everyday life with all my heart. Character education as an educational concept that instills character that involves aspects of knowledge (cognitive), feelings, and actions is a solution to improve the character and morals of the nation. Practically, character education is a system of instilling good values in the school or campus community that includes components of knowledge, awareness or will, and actions to carry out these values, both in dealing with God Almighty, fellow humans, the environment, as well as the homeland and the nation so that it becomes a whole person. ${ }^{16}$

In a simple explanation, character education can be defined as any effort that can be made to influence student character. However, to find out the right understanding, it can be stated here the definition of character education delivered by Thomas Lickona. Lickona states that character education is a deliberate effort to help someone so that he can understand, pay attention, and carry out core ethical values. Starting with that definition, when we think about the types of characters we want to build in students, it is clear that at that time we want them to be able to understand these values, pay closer attention to the truth of those values, and then do what he believes in, even though he must face challenges and pressures both from outside and from within. In other words they have 'consciousness to force themselves' to

16 Diptasari Wibawanti, "Persepsi dan Perilaku Mahasiswa dalam Pendidikan Karakter (Studi Kasus di Jurusan Pendidikan Ilmu Pengetahuan Sosial Fakultas Keguruan dan Ilmu Pendidikan Universitas Sebelas Maret)", SOSIALITAS: Jurnal Ilmiah Pend. Sos. Ant., 3(1), 2013, pp. 1-16. https://jurnal.fkip.uns.ac.id/index.php/sosant/article/view/867 
do those values. ${ }^{17}$ Furthermore, in character education, Lickona emphasized at least there are ten essential virtues for student as shown on Table 1.

Table 110 Essential Virtues

\begin{tabular}{|c|c|c|}
\hline No & Essential Virtues & Application \\
\hline \multirow[t]{3}{*}{1} & Wisdom & $\begin{array}{l}\text { 1) Good judgment; ability to make reasoned } \\
\text { decisions }\end{array}$ \\
\hline & & 2) Knowing how to put the virtues into practice \\
\hline & & $\begin{array}{l}\text { 3) Discerning what's important in life; ability to } \\
\text { set priorities }\end{array}$ \\
\hline \multirow[t]{6}{*}{2} & Justice & 1) Fairness (following the Golden Rule) \\
\hline & & 2) Respect \\
\hline & & 3) Responsibility \\
\hline & & 4) Honesty \\
\hline & & 5) Courtesy/civility \\
\hline & & $\begin{array}{l}\text { 6) Tolerance (respect for freedom of conscience, } \\
\text { exercised with respect for the rights of others) }\end{array}$ \\
\hline \multirow[t]{6}{*}{3} & Fortitude & 1) Courage \\
\hline & & 2) Resilience \\
\hline & & 3) Patience \\
\hline & & 4) Perseverance \\
\hline & & 5) Endurance \\
\hline & & 6) Self-confidence \\
\hline \multirow[t]{6}{*}{4} & Self-Control & 1) Self-discipline \\
\hline & & $\begin{array}{l}\text { 2) Ability to manage one's emotions and } \\
\text { impulses }\end{array}$ \\
\hline & & 3) Ability to delay gratification \\
\hline & & 4) Ability to resist temptation \\
\hline & & 5) Moderation \\
\hline & & 6) Sexual self-control \\
\hline \multirow[t]{6}{*}{5} & Love & 1) Empathy \\
\hline & & 2) Compassion \\
\hline & & 3) Kindness \\
\hline & & 4) Generosity \\
\hline & & 5) Service \\
\hline & & 6) Loyalty \\
\hline
\end{tabular}

17 Thomas Lickona, Educating for Character: How Our School Can Teach Respect and Responsibility, New York, Bantam Books, 1991, pp. 134-136. Thomas Lickona, "Make Your School A School of Character", on Character Matters, 2004, retrieved from www.cortland.edu/character. 


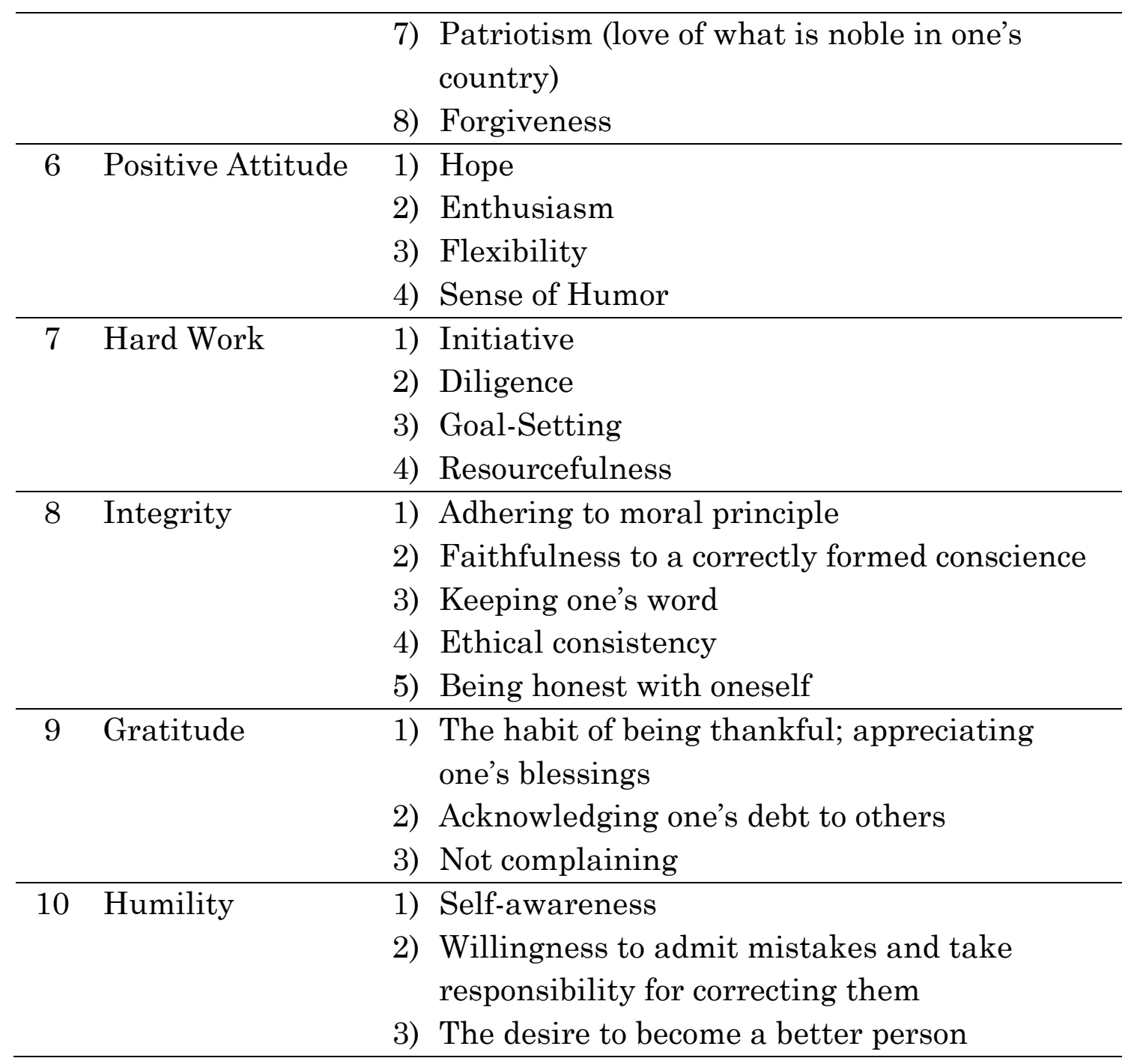

\section{The Implementation of Character Education for Law Student Activits}

Character education can be interpreted as value education, character education, moral education, character education, which aims to develop the ability of students to make bad decisions, maintain what is good, and realize that goodness in everyday life with all my heart. ${ }^{18}$ Formation and character development as an educational effort are expected to have a positive impact both on individuals and the environment. This is according to the opinion of Megawangi that character education is an attempt to educate children in

18 Udin Saripudin Winataputra, "Implementasi Kebijakan Nasional Pembangunan Karakter Bangsa melalui Pendidikan Karakter", 2010, retrieved from https://kisyani.files.wordpress.com/2010/07/makalah-1.pdf 
order to make decisions with wise and practice it in everyday life, so they can make a positive contribution to their environment. ${ }^{19}$

The Ministry of National Education prepares Parent Education Design Character, which is a paradigmatic framework for the implementation of national character development through the education system. Overall character education in the Character Education Master Design is as follows: a. In the macro character development can be divided into three stages, namely planning, implementation, and evaluation of results. At the planning stage, a character set is developed which is dug up, crystallized, and formulated using various sources, including considerations: (1) philosophical - Religion, Pancasila, the 1945 Constitution, and Law No. 20 of 2003 along with the provisions of its derivative legislation; (2) theoretical considerations - theories about the brain (brain theories), psychological (cognitive development theories, learning theories, theories of personality) education (theories of instruction, educational management, curriculum theories), values and morals (axiology, moral development theories), and socio-cultural (school culture, civic culture); and (3) empirical considerations in the form of experiences and best practices from among others figures, leading education units, messages, cultural groups, etc.

b. At the implementation stage, learning experiences are developed and the learning process leads to the formation of characters in individual students. This process is carried out through the process of acculturation and empowerment as outlined as one of the principles of the implementation of national education. This process takes place in three pillars of education namely in the education unit, family, and community. In each pillar of education there will be two types of learning experiences that are built through two approaches namely intervention and habituation. In the intervention an atmosphere of learning and learning interaction is developed that is intentionally designed to achieve the goals of character building by implementing structured learning experiences. In order for the learning process to be effective the teacher's role as a role model is very important and decisive. Meanwhile, in a habituation, situations and conditions are created (persistent life situation), and reinforcement that enables students in their education units, in their homes, in their communities to get used to behaving according to values and become characters that have been internalized and personalized from and through intervention process. The process of civilizing and

19 Megawangi, Op.Cit..; Kesuma, D., Triatna, C., \& Permana, J. (2011). Pendidikan Karakter Kajian Teori dan Praktik di Sekolah. Bandung: Remaja Rosdakarya. 
empowering which includes modeling, learning, accustoming, and strengthening must be developed systemically, holistically, and dynamically.

c. In the macro context of Indonesian national and state life. The implementation of character education is a commitment of all sectors of life, not only the national education sector. Active involvement from other government sectors, specifically the religious sector, welfare, governance, communication and information, health, law and human rights, as well as youth and sports.

d. At the results evaluation stage, a program assessment is carried out for continuous improvement that is deliberately designed and implemented to detect the actualization of character in learners as an indicator that the process of culture and character empowerment is successful.

Character education is expected to produce change behavior that leads to more positive. Behavior has a subjective meaning for each culprit. Weber (1964) states that an action is a human behavior that has a subjective meaning for the culprit. ${ }^{20}$ Understanding the subjective meaning of an action means being empathetic, that is, how to put yourself in the frame of mind of another person who is doing the action, and the situation and goals seen according to that perspective. Character education is a conscious effort that considers goals and ways to achieve them. By Weber, this is referred to as an instrumental rational act, which includes conscious considerations and choices related to the goals and tools used to achieve them.

As explained above, understanding the character education as well as the importance of character education for students, because through this character education a student character will be formed which upholds the values of Pancasila, namely, such as honesty, politeness, togetherness and religious. Therefore the Student Executive Board of the Law Faculty of Semarang State University in collaboration with the community services program team of the Unnes Law Faculty lecturer held a character education training program for law school student activists.

This activity was attended by representatives from each of the existing law faculties, this training activity was held for two days, from October 26 to October 27, 2019 with the theme "Preparing Active, Smart, Critical and Pancasila Characteristic Students to Realize Resources Indonesia's Superior Citizens."

This training presents 4 (four) material programs in which the expectations delivered by the presenter can be understood by students and

20 Sunarto, K, Pengantar Sosiologi (edisi revisi). Jakarta: Lembaga Penerbit Fakultas Ekonomi Universitas Indonesia, 2004, pp. 45-47. 
implemented in the life of society, nation and state. The programs are: (1) Public Speaking, (2) student idealism, (3) advocacy and the role of students in advocacy, and (4) self-motivation and therapy to shape character.

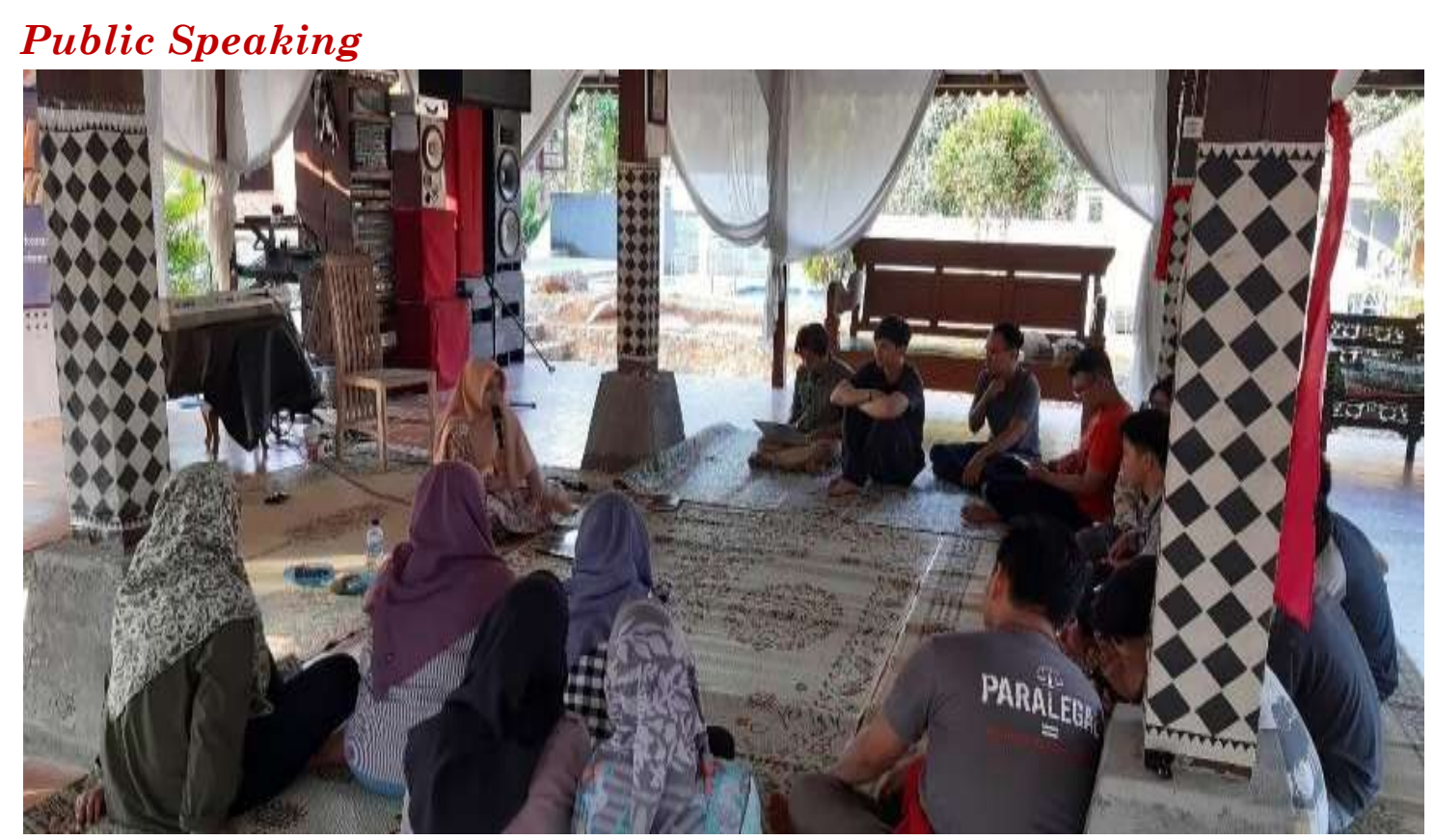

Fig. 1 Public Speaking Training for Law Student. Doc: Authors, October 2019

This activity begins with playing a motivational video as a prelude to opening public speaking material, the video is a series of aspirations of someone written in a paper, then the speaker stresses the urgency of public speaking towards life, the urgency of public speaking is the procedure for conveying information from each education level, public speaking must be guarded with politeness as a wrapper for that matter. Intelligence must be escorted by good character, to be honest the values of good ethical congress and already stated in the values written are Pancasila, Pancasila is a characteristic of the people of Indonesia that should be reflected by Indonesian people. Soft skills is actually one of the abilities that will never be over we train, because every moment sometimes requires different specifications in each time, the essence of training public speaking is to add experience so that the more semiif we add to our experience then this skill will improve.

Farhan Raja emphasized that most people are not born public speakers; they are trained to become one. When they find themselves in situations where they become the focus of attention as they have to address an audience, they experience emotions like fear and anxiety, leading to nausea and excessive sweating. Most of them try to avoid situations where 
they have to perform or speak in public, but when unavoidable, such situations are endured by distress. ${ }^{21}$

\section{Student Idealism}

Tells the twists and turns of the socio-political journey 2017 of BEM KM UNNES, Haris (the Speaker) recalls his memories of a long time ago as a student. Study and science are at the heart of the idealism of today's students, students as academic people should color their life activities with an academic nuance, although there Haris tells how extensive the problems can be dissected as a social study. Study is one of the academic nutrition possessed by students.

The idealism of students in seeing problems is the most expensive treasure possessed by students as youth, Haris asserted that objectivity and intelligence raciality are the last barn of honesty possessed by humans on earth, so students are one of the last fences. So that the core idealism that students must do is become an objective human being according to their capacities as humans. At present, Haris, who has a sensitivity at LBH Semarang, also recognizes that capital having objective knowledge is the key to responding to social problems that arise in the community. For Haris, the problem at this time was born from the community's ignorance of the solution that should be used, this which is still evidence of the exclusion of special knowledge in the higher education academic community.

Furthermore, in the context of idealism, philosophically, idealism is the diverse group of metaphysical philosophies which asserts that "reality" is in some way indistinguishable or inseparable from human understanding and/or perception; that it is in some sense mentally constituted, or otherwise closely connected to ideas. ${ }^{22}$ According to Immanuel Kant, a pioneer of modern idealist thought, idealism does "not concern the existence of things", but asserts only that our "modes of representation" of them, above all space and time, are not "determinations that belong to things in themselves" but essential features of our own minds. ${ }^{23}$ Kant called this position "transcendental" and "critical" idealism, since it describes the way in which "reality" is utterly transcended by, and cannot be thought separate from, the categories with which they are structered by and in human understanding.

21 Farhan Raja, "Anxiety Level in Students of Public Speaking: Causes and Remedies." Journal of Education and Educational Development, 4(1), 2017, pp. 94-110.

22 "Idealism I philosophy". Encyclopedia Britannica. Retrieved 22 January 2020

23 Guyer, Paul; Horstmann, Rolf-Peter (2019), Zalta, Edward N. (ed.), "Idealism", The Stanford Encyclopedia of Philosophy (Winter 2019 ed.), Metaphysics Research Lab, Stanford University, retrieved 22 January 2020 
And, epistemologically, idealism manifests as a skepticism about the possibility of knowing any mind-independent thing. In contrast to materialism, idealism asserts the primacy of consciousness as the origin and prerequisite of phenomena. Idealism holds consciousness or mind to be the "origin" of the material world - in the sense that it is a necessary condition for our positing of a material world - and it aims to explain the existing world according to these principles. ${ }^{24}$

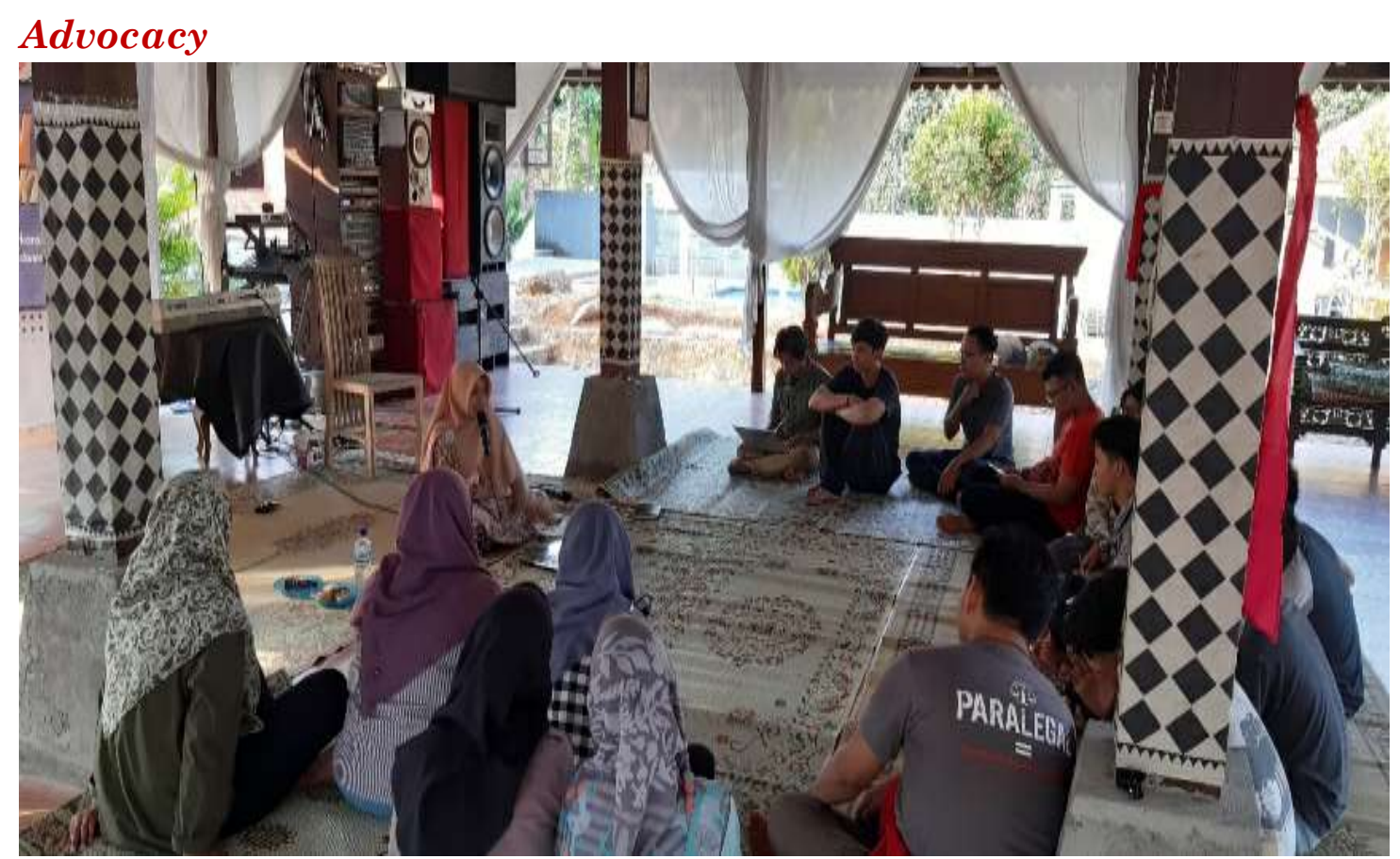

Fig. 2. Advocacy activitity, The Speaker explaining about advocacy to Law Student of UNNES. Doc: Authors, October 2019

The activity starting by making an agreement by creating a forum is not the same as a seminar, which is rigid one-way but two-way active. One function that must be owned by students is the advocacy function, there is no standard definition of advocacy but can be stripped down as a series of processes to change public policy, then the speaker invites participants to study social issues that can be advocated.Advocacy is one of the soft skills that is the basis of the science of law, the meaning of the word advocacy is to solve problems properly and corporatively, Advocacy is an activity where we must act well to create a voice of justice, a voice of justice departing from the voice of honesty. Honesty is a noble moral value, indeed in a culture of democracy there is a culture of transparency as a public answer, but long

24 Embree, Lester; Nenon, Thomas, eds. (2012). Husserl's Ideen (Contributions to Phenomenology). Springer Publishing. p. 338. ISBN 9789400752122. Retrieved 27 October 2019. 
before that Indonesia had a very high noble value, namely the value of easternness, which is honesty, in the forum, Frans also talked a lot about his experience in advocating many things, especially issues student on Campus. Advocacy is the life of the practice of looking for justice in a real and real way among students, advocacy as a means and a place for self-improvement and the sharpness of conscience in reading situations and conditions and the reality of people's lives.

Advocacy itself recognized as an activity by an individual or group that aims to influence decisions within political, economic, and social institutions. Advocacy includes activities and publications to influence public policy, laws and budgets by using facts, their relationships, the media, and messaging to educate government officials and the public. Advocacy can include many activities that a person or organization undertakes including media campaigns, public speaking, commissioning and publishing research. Lobbying (often by lobby groups) is a form of advocacy where a direct approach is made to legislators on a specific issue or specific piece of legislation.

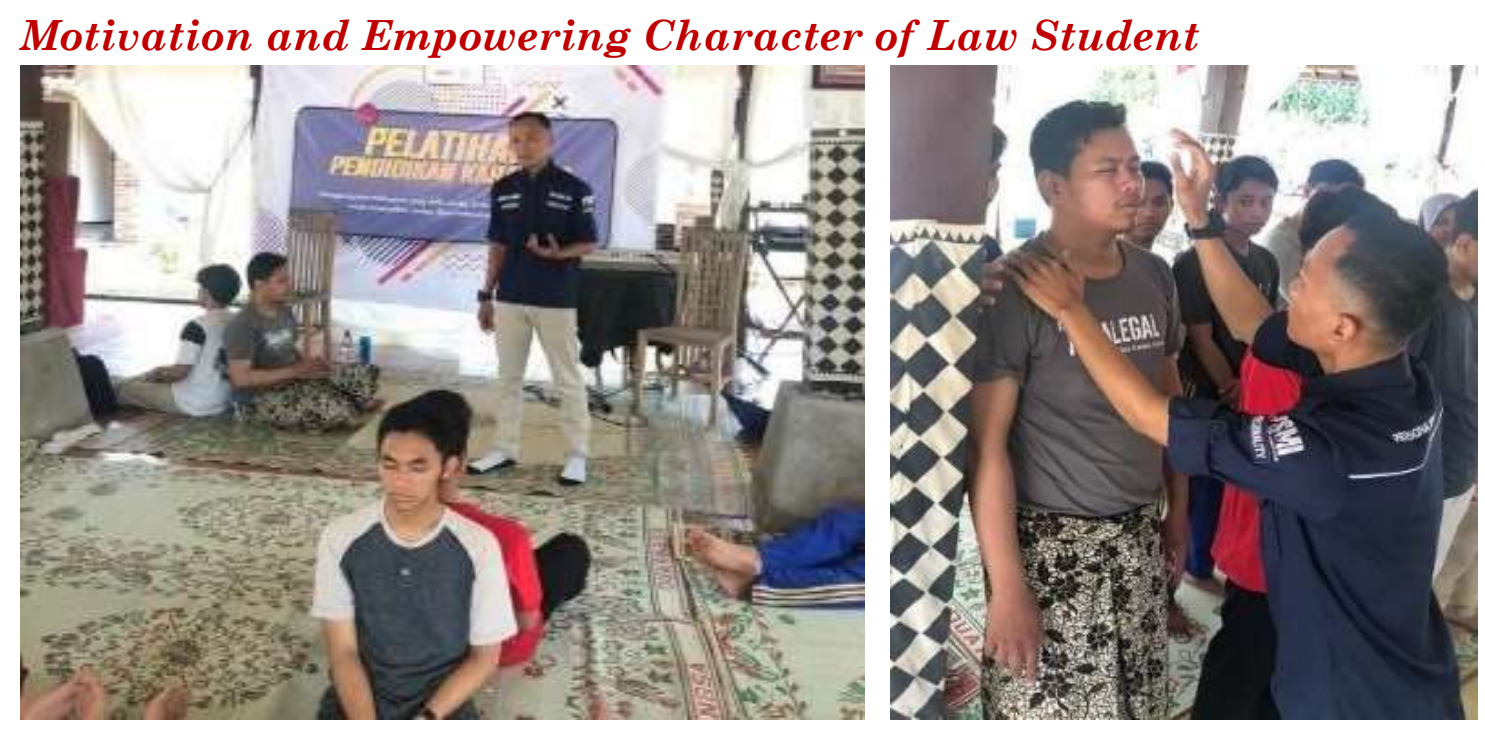

Fig. 3. Motivation by relaxing the participants. Doc: Auhtors, October 2019

The speaker is relaxing and motivating the participants, so as to motivate and relax themselves so that positive things appear by calming down, looking for good and calm comfort for self reflection and introspection. The speaker is relaxing the participants, asking that participants release all negative things that are in their minds. Participants are invited to imagine themselves in a very calm and peaceful place, there are bird sounds, wind sounds, water sounds that make participants relax. 
In this session, student activists were directed in such a way as to be sure and strengthen their positive character through various inputs.

\section{Conclusion}

Character education through strengthening the values of Pancasila, patriotism, nationalism and religiosity for law students, especially student activists, is highly needed amidst the era of modernization, globalization and the industrial revolution 4.0. The challenges facing students today continue to develop, so we need to strengthen positive characters that are able to have a significant impact on student activists in surviving in the real world. Strengthening the good character of Pancasila through public speaking, strengthening student idealism, strengthening advocacy capacity, and defending human rights are the basis for law students in their daily lives. Strengthening these characters is also useful for future provisions in choosing suitable jobs later.

\section{E. Acknowledgments}

Authors would like to express the thakfullness to Faculty of Law, Universitas Negeri Semarang, as well as to Law Student Union at Faculty of Law Universitas Negeri Semarang for supporting this research.

\section{F. Declaration of Conflicting Interests}

The authors state that there is no potential conflict of interest in the research, authorship, and/or publication of this article.

\section{G. Funding}

The research funded by Faculty of Law Universitas Negeri Semarang, Indonesia.

\section{H. References}

Ajisuksmo, C. (2010). "Pendidikan Karakter, Proceedings, Konferensi Nasional \& Workshop Assosiasi Psikologi Pendidikan Indonesia, October. 
Arifin, R., Alkadri, R., Sari, D.P., Resthiningsih, L., \& Holish, A.M. (2019). Improving Law Student Ability on Legal Writing through Critical and Logical Thinking by IRAC Method, Indonesian Journal of Advocacy and Legal Services, 1(1), 107-128. https://doi.org/10.15294/ijals.v1i1.33706

Arifin, R., Waspiah, W., \& Latifiani, D. (2019). Penulisan Karya Ilmiah untuk Mahasiswa Hukum. Semarang, BPFH UNNES.

Arifin, R. (2020). Crimes and Society, How Do the Law Respond to Disruptive Conditions?, Law Research Review Quarterly,6(1), 2020, i-iv. Retrieved from https://journal.unnes.ac.id/sju/index.php/snh/article/view/37437

Arifin, R. (2020). "Legal Reform Discourse in Indonesia and Global Context: How Does the Law Respond to Crime", Journal of Law and Legal Reform, 1(2), 193-196. https://doi.org/10.15294/jllr.v1i2.37057

Embree, L., \& Thomas, N. (eds). (2012). Husserl's Ideen (Contributions to Phenomenology). Springer Publishing.

Ferdyant, F. (2018). Tantangan-Tantangan dalam Pendidikan Karakter: Catatan Awal Tahun 2018 IKA UNJ, https://unjkita.com/tantangantantangan-dalam-pendidikan-karakter-catatan-awal-tahun-2018-ikaunj/

Guyer, P., \& Rolf-Peter, H. (2019). "Idealism", The Stanford Encyclopedia of Philosophy (Winter 2019 ed.), Metaphysics Research Lab, Stanford University, retrieved 22 January 2020.

Hidayat, R. (2014). "Robohnya Moralitas Kampus", Republika Online, 17 November 2014, https://republika.co.id/berita/nf6agc45/robohnyamoralitas-kampus

"Idealism | philosophy". Encyclopedia Britannica. Retrieved 22 January 2020

Khaeriah, E. (2011). "Konsep Pengembangan Pendidikan Karakter Sebagai Pembentuk Identitas Diri Remaja dalam Perspektif Teori Identitas Erikson (Studi Kritis di SMK Negeri 2 Malang)", Master Thesis. Malang: Universitas Muhammadiyah Malang.

Kesuma, D., Triatna, C., \& Permana, J. (2011). Pendidikan Karakter Kajian Teori dan Praktik di Sekolah. Bandung: Remaja Rosdakarya.

Kompas. (2012, December). $\quad$ Retrieved from www. http://internasional.kompas.com.

Lickona, T. (1991). Educating for Character: How Our School Can Teach Respect and Responsibility. New York: Bantam Books. 
Lickona, T. (2004). "Make Your School A School of Character", on Character Matters, retrieved from www.cortland.edu/character.

Marzuki, M. (2012). Pengintegrasian Pendidikan Karakter dalam Pembelajaran di Sekolah. Jurnal pendidikan Karakter, 2(1), 33-44. DOI: https://doi.org/10.21831/jpk.v0i1.1450.

Megawangi, R., (2010). "Strategi dan Implementasi Model Pendidikan Holistik Berbasis Karakter", Proceedings, Konferensi Nasional \& Workshop Assosiasi Psikologi Pendidikan Indonesia, October.

Niravita, A. (2019). The Role of Law Students on Strengthening Village Human Resources in the Era of the Industrial Revolution 4.0, Indonesian Journal of Advocacy and Legal Services, 1(1), 2019, 1-4. https://doi.org/10.15294/ijals.v1i1.33802.

Raja, F. (2017). Anxiety Level in Students of Public Speaking: Causes and Remedies. Journal of Education and Educational Development, 4(1), 94-110.

Rose Mini, A.P., (2010). "Perkembangan Moral sebagai Dasar Pendidikan Karakter Anak, Proceedings, Konferensi Nasional \& Workshop Assosiasi Psikologi Pendidikan Indonesia, October.

Ryan, K., \& Bohlin, K.E. (1999). Building Character in Schools: Practical Ways to Bring Moral Instruction to Life. San Francisco: JOSSEY-BASS A Wiley Imprint.

Sartono, H.M. (2011). "Pengintegrasian Pendidikan Karakter dalam Pengembangan Kurikulum Tingkat Satuan Pendidikan”, Online, from http://www.slideshare.net/sarhaji/pengintegrasianpendidikankarakter-

Sawitri, D.R., \& Arianti, J. (2010). "Malas, Ngantuk, Bosan: Hambatan Mahasiswa untuk Mencapai Indeks Prestasi Tinggi”, Proceedings, Konferensi Nasional dan Workshop Asosiasi Psikologi Pendidikan Indonesia, pp. 211-215.

Semiawan, C.R. (2010). "Peran Pendidikan dalam Pembangunan Karakter Bangsa", Proceedings, Konferensi Nasional \& Workshop Assosiasi Psikologi Pendidikan Indonesia, October.

Sudrajat, A. (2011). Mengapa Pendidikan Karakter?, Jurnal Pendidikan Karakter, 1(1), 47-58.

Sunarto, K. (2004). Pengantar Sosiologi (edisi revisi). Jakarta: Lembaga Penerbit Fakultas Ekonomi Universitas Indonesia, 2004, pp. 45-47.

Wibawanti, D. (20130. "Persepsi dan Perilaku Mahasiswa dalam Pendidikan Karakter (Studi Kasus di Jurusan Pendidikan Ilmu Pengetahuan Sosial Fakultas Keguruan dan Ilmu Pendidikan Universitas Sebelas 
Maret)", SOSIALITAS: Jurnal Ilmiah Pend. Sos. Ant., 3(1), 1-16. https://jurnal.fkip.uns.ac.id/index.php/sosant/article/view/867

Winataputra, U.S. (2010). "Implementasi Kebijakan Nasional Pembangunan Karakter Bangsa melalui Pendidikan Karakter", Online, retrieved from https://kisyani.files.wordpress.com/2010/07/makalah-1.pdf

Zuriah, N. (2007). Pendidikan Moral dan Budi Pekerti Dalam perspektif Perubahan. Jakarta: Bumi Aksara. 
A. Niravita, et.al.

\title{
Quote
}

\author{
"Der Mensch kann tun was er will; \\ er kann aber nicht wollen was er \\ will.
}

\section{Man can do what he wills but he cannot will what he wills."}

\author{
Arthur Schopenhauer \\ Essays and Aphorisms
}

Copyrights (C) 2020 by Auhtor(s). This work is licensed under a Creative Commons Attribution-NonCommercial-ShareAlike 4.0 International License. All writings published in this journal are personal views of the authors and do not represent the views of this journal and the author's affiliated institutions. 